\title{
ANTIGONE AT COLONUS AND THE END(S) OF TRAGEDY
}

\section{Brooke Holmes}

Sophocles' Oedipus at Colonus, it would seem, is an exercise in closure. In the opening scene, Oedipus, worn down by years of wandering blind and hungry, arrives at the borders of Athens. Here is where his legendary sufferingshis murder of his father, his incestuous marriage to his mother, his betrayal by his sons, his exile from Thebes-are fated to end. Following his miraculous death, his body will become a sacred gift to the city that receives him, protecting it against future attack. In the closing moments of the play, everything unfolds according to plan. Oedipus disappears offstage and mysteriously descends into the earth. The king of Athens, Theseus, alone marks the spot of his disappearance, knowledge he will pass down to his sons as part of his responsibility to the city. By the end of the tragedy, then, Oedipus has made his way home to the gods in a land capable of honouring his awesome, singular fate.

The concept of 'coming home' is integral, as this précis suggests, to the play's logic of closure.' Yet, crucially, it governs only one of the two planes on which the drama unfolds, that of the gods. Oedipus' life has been in the hands of the gods since before he was born. That they reclaim him at the end of his life gives his exit the feel of a return. By contrast, the path to Athens, for all its meandering, is not circular but linear. Athens is definitively not Thebes, as the tragedy demonstrates over and over (nor is it Corinth, Oedipus' other point of origin). Thebes is, rather, the home that Oedipus rejects, most spectacularly through his resistance to Creon's demand that he return to the city of his birth. What is more, he repudiates any relationship to the Theban throne. When Polyneices arrives to ask his father to support his bid to reclaim the kingship from his brother Eteocles, Oedipus does not simply refuse to intervene but drives his son away with curses. His refusal is a refusal not just of Thebes but of the Labdacid line altogether (he goes so far as to call Polyneices $\alpha \dot{\alpha} \alpha \tau \omega \mathrm{Q}$, 'fatherless',

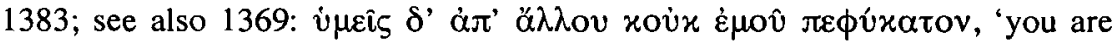
from another and not born from me'); his pact with Theseus creates an alternate genealogy of fathers and sons. Seen in this light, Oedipus' arrival at Colonus and, ultimately, his dramatic exit become the final stages of a process not of coming home but of leaving Thebes behind and with it 'the radical tragic terrain where there can be no escape from the tragic in the resolution of conflict or in the institutional provision of a civic future beyond the world of the play'.

Oedipus' exit, however, is not the end of the story. Surprisingly, in view of the tragedy's drive towards closure, the final scene bears a kernel of volatility. ${ }^{3}$ Once Oedipus leaves the stage, together with his daughters, Antigone and Ismene, and Theseus, we have a messenger speech reporting on the events offstage. Most notable is Oedipus' mysterious disappearance, 'viewed' in a mediated way through its effect on its sole witness (the messenger sees Theseus 
'holding his hand before his face to screen his eyes, as if some dread sight had been seen, and such as none might endure to behold', 1650-52).

The stage at this point is given over to the survivors. First to return are Oedipus' daughters, who enter loudly mourning. They are followed by Theseus, who tells them to stop. Antigone, whom Euripides once called a bacchante of corpses (Pho. 1489f.), erupts with a demand to see her father's grave. Theseus, in turn, reiterates Oedipus' command that no one, save Theseus himself and his sons, should know the whereabouts of his tomb. Indeed, the security of Athens depends on Theseus keeping this secret. Given Antigone's reputation for defiance, we might expect a conflict here. Instead, she accepts the king's explanation and turns her attention to the impending fratricide at Thebes. She asks Theseus for help getting home, and he is only too happy to grant her request: escorting Antigone out of Athens is arguably the smartest thing he does in the play. For it is Antigone who is the volatile element that threatens not just the tragedy's resolution but its very drive toward resolution, the glitch in the Sophoclean machine. Her destabilising potential bears precisely on the question of where Oedipus' home lies and, indeed, where she herself belongs.

Yet Antigone's significance is not immediately apparent: it is not an accident that in an essay about Antigone it has taken some time to get to her. For the very incandescence of Oedipus at the end of his life can blind us to the daughter who has been supporting him for so long. Antigone's shadowy presence can explain, in turn, why the play has had little impact on the enthusiastic postmodern canonisation of Antigone in the wake of influential readings by Jacques Lacan, Luce Irigaray and Judith Butler. ${ }^{4}$ Simply put, Antigone at Colonus is not the Antigone we expect. She lacks the terrifying singlemindedness of the character who dominates the Antigone. In fact, for most of the tragedy she is downright anemic. When critics have established a line of continuity between the two Antigones, they have pointed to her frenzied reappearance at the end of the play and her departure for Thebes. Indeed, there is a virtual consensus that the last scene foreshadows the tragedy of the Antigone. ${ }^{5}$ The main interest of the Coloneus for aficionados of Antigone thus lies in its status as a prequel: a glimpse of Antigone on her way to becoming an icon. ${ }^{6}$ Her story picks up only where Oedipus' leaves off.

There are two reasons for seeing this approach as inadequate. Each invites us to reconsider Antigone's role in the play. First, a 'prequel' reading, in its impatience for the familiar icon, sidesteps the question of why Antigone is so tractable in the Coloneus. I try to account for what is at stake in her tractability by showing how it facilitates one of the most important trajectories in the playnamely, the transfer of Oedipus from the care of his daughters, especially Antigone, to the protection of the city. The transfer parallels the rejection of the more obvious rival claims on Oedipus' sacred power: those of Creon and Polyneices. Yet it is also more delicate. For if Oedipus' relationship to these two men is electrified by hatred, he is bound to his daughters by love and the 
trophe, 'care', born from that love. One of the tasks of the Coloneus, I argue, is to extricate Oedipus from the props and claims of filial love.

But what kind of claim do Oedipus' daughters - and again, especially Antigone-have on their father's precious corpse? They are not, after all, allied with a state. Then again, this is exactly the point. It is precisely because the daughters represent another, probably older story of Oedipus' death, one in which the relationship to politics is less straightforward, that their presence is an implicit challenge to the belated political claims on their father's body. Recall that the Antigone of Sophocles' eponymous tragedy, probably staged over three decades before the Coloneus, makes the body of Oedipus a crucial part of her story. Her commitment to burying her brother Polyneices in the Antigone builds on her earlier burial of her mother and her father, who is said in that play, as in other texts, to have died hated in Thebes. ${ }^{7}$ She addresses them in her final kommos: 'when you died, I with my own hands washed and dressed you

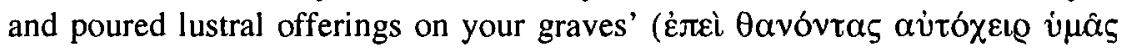

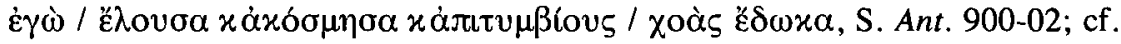
49-54). In the Antigone, Oedipus in death belongs to Antigone.

In the Coloneus, however, Antigone's claim on her father's body is thwarted. Although she, together with Ismene, ritually prepares him for death while he is still living, his body is ultimately entrusted to the polis. Nevertheless, the tragedy arrives at this outcome only after a muted but sustained tug-of-war between Antigone and Athens. In what follows, I track the displacement of Oedipus' corpse from what we might call the 'burial plot' of the family and all it represents, a displacement that rewrites the conflict between Antigone and Creon in the earlier play. If at Thebes, Antigone is defined by her resistance to a tyrant who refuses to recognise the still-sacred status of a polluted corpse, on the borders of Athens, she faces a city that embraces the abject body as its sacred talisman and a ruler who is himself an enemy of tyrants. The challenge that Antigone poses to the city changes, then, when the city is not Thebes, but Athens. It is expressed far more subtly than it is in the Antigone. Moreover, Antigone's pliability at the end of the play spares Athens the costs of more overt defiance, while raising the question of where she will direct the powerful energies that surface in her at the end of the play.

The ways in which the Coloneus repeats and reworks motifs from the Antigone bring us to the second snag in the 'prequel' reading of Antigone at Colonus: its failure to take seriously the complicated chronology of Sophocles' so-called 'Theban cycle'. The three plays of the cycle, Antigone, Oedipus Tyrannus, and Oedipus at Colonus, are by no means a standard trilogy. They were most likely performed decades apart from one another. Equally important, the order in which they appear-probably the Antigone (ca. $442 \mathrm{BCE}$ ), followed by the Oedipus Tyrannus (ca. $428 \mathrm{BCE}$ ), and then the Coloneus (performed posthumously in $401 \mathrm{BCE}$ )-does not follow the order of events in the mythological narrative: first, Oedipus' downfall (Oedipus Tyrannus), then his exile and death (Oedipus at Colonus), and finally Antigone's death at Thebes (Antigone). 


\section{BROOKE HOLMES}

What this means is that the allusions weaving the plays together operate in nonlinear and unpredictable ways.

More specifically, the Oedipus at Colonus stands in the position of recoding the tragedies that precede it. We see this in the intricate patterns of repetition through which, as Bernd Seidensticker and others have demonstrated, the Coloneus revisits acts and themes from the Oedipus Tyrannus. ${ }^{8}$ I argue that a similar process of resignification occurs in relationship to the Antigone. The twist is that, in the case of the Antigone, the Coloneus is destabilising and reworking not the past but the future. How can we assume, then, that we know what happens after Antigone leaves Athens? Recall Antigone's fate in Euripides' Phoenissae, where her decision to accompany Oedipus into exile, taken after the fratricide, seems to exclude the burial of Polyneices (and leaves the question of Antigone's ultimate fate completely open). ${ }^{9}$ For all that the Coloneus seems to hurtle us toward the destruction of the last generation of Labdacids at Thebes, then, on closer examination we can see that the story of Antigone's final days in exile with her father, in rewriting the burial plot of the Antigone, transforms our sense of who she is and where she is going.

That the Coloneus has the power to destabilise the familiar Antigone and our expectations for her future has also been argued by Andreas Markantonatos. ${ }^{10}$ Yet whereas for Markantonatos, Antigone is transformed by her time in Athens, educated by Theseus in Athenian ideals and cast for us as 'an Athenian agent par excellence, ', I read a persistent if subtle antagonism between Antigone and Athens that invites us to consider what it means for Antigone not to belong to Athens. That non-belonging can be read in terms of Antigone's commitment in the final scene to the aversion of conflict at Thebes, her hopefulness, and the motivation of her actions in terms of love. In these respects, she stands against the installment of Oedipus at Athens' border as an apotropaic force of hatred.

But we can also go further and take the Oedipus at Colonus as an invitation to reimagine tragic futurity and the afterlife of tragedy more generally. By refusing to take the Antigone of the Antigone as the secure endpoint of the later play, we open ourselves up to imagining how Antigone at Colonus, not yet wedded to death, is oriented towards an uncertain future, rich in unexpected possibilities. If Oedipus' burial at Athens arrests his sacred power within the territory of the ancient city-state and harnesses it to its ends, Antigone's exit can be read as a tautly calibrated springboard that enables us to reimagine her beyond the boundaries of Athens. The structure of the final scene would then marry the pluripotency of myth to the rich reception tradition that has developed around Antigone, especially in the last few decades. The very nature of the play, in other words, allows for both its rootedness in Athenian territory and its centrifugal reverberations into an ever evolving future. Does an Antigone figured as the guardian of such openendedness undercut the very qualities that have made Antigone so attractive to modern readers: her singlemindedness, her unwavering commitment to honouring her brother in death, her disregard of 
death? In closing, I suggest that Antigone at Colonus, in allying herself with life rather than death, does not so much displace our other Antigone(s) as raise questions about what it means to read tragedy as both a dead language and a dynamic organism.

The process by which Oedipus is shifted out of Antigone's hands to the care of the city is subtle. I cannot track every twist and turn. Nevertheless, my aim in what follows is, first, to defend my claim by attending patiently to how relationships are established spatially and through language, focusing on the first and last scenes of the play. In the last section, I reflect more broadly on strategies of reading that are capable of negotiating between the specificities of the text and its openended future.

\section{The Obsolete Prop}

The paradox of Antigone at Colonus begins with her presence in the drama. On the one hand, she is on stage for nearly the entire play. Given her abrupt departure two thirds of the way through the Antigone, her staying power here is interesting in itself. On the other hand, she is largely peripheral to the tragedy's main events. She is literally her father's auxiliary. Oedipus himself implicitly casts her as a prosthesis when he speaks of 'walking by the eyes of others and

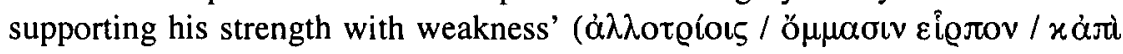

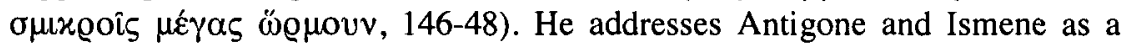

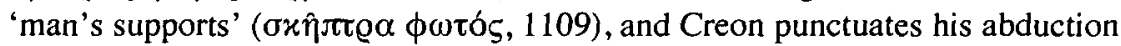
of Antigone with a jibe at Oedipus: 'you won't be travelling on those crutches

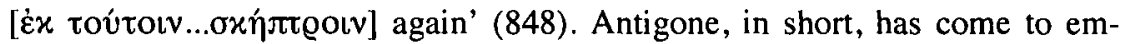
body the skeptron that counts as man's third leg in his twilight years according to the riddle of the Sphinx that Oedipus solved long ago at great cost, paving the route to his daughter's monstrous birth.

Yet, on closer examination, the figure of Antigone qua prop is itself a provocation. We can see this in the way her entrance plays with our expectations. The fact that she enters supporting a blind man casts her as an attendant, a character often used to lead (blind) seers, such as Teiresias, onstage. ${ }^{12}$ The first line, however, breaks theatrical convention in having Oedipus name (and

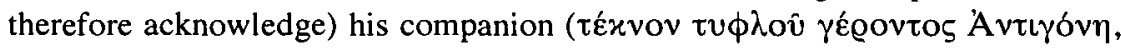
' $O$ child of a blind old man Antigone'), preparing us for an even more surprising moment: the attendant, usually a supernumerary - that is, a mute actorspeaks. Despite the fact, then, that Antigone initially appears as the conventionally silent support to the mouthpiece of divine knowledge, her entrance at the level of dramatic discourse signals that she is no conventional prop.

The very visibility of Antigone draws attention to Oedipus' need for her support. He is, at the beginning, very much the wanderer and the dependent. His first words take the form of a question to Antigone: 'What lands have we

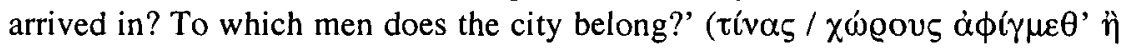

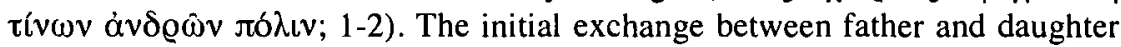
inscribes their symbiosis into a long history. 'Seat me', Oedipus commands 
Antigone, after what must have been a prolonged and arduous entrance on

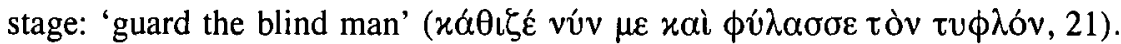

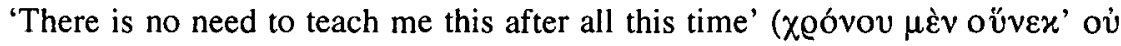
$\mu \alpha \theta \varepsilon i ̂ v ~ \mu \varepsilon \delta \varepsilon \hat{\imath} \tau o ́ \delta \varepsilon, 22)$, Antigone replies. And yet, by the end of the play, Oedipus will be capable of supporting and guiding himself, aided only by the gods. Sophocles' initial emphasis on Oedipus' vulnerability thus has a purpose, establishing a starting point for the arc of the hero's development over the course of the play. Antigone's presence, insofar as it makes obvious Oedipus' still imperfect knowledge at the beginning of the tragedy and the distance separating him from the hero he is on his way to becoming, plays an important role in this plan. Recognising this, we can predict her increasing obsolescence as Oedipus' transformation unfolds.

The transformation gets under way quickly. The seat Oedipus takes with Antigone's help marks an initial step toward his fated end, as we learn when the first local appears and announces that the foreigners have trespassed in the sacred grove of the Eumenides. Far from expressing horror at what he has done, Oedipus declares that he has reached his final resting place, citing for the first time the 'watchword' of his fate ( $\xi v \mu \phi o \varrho \alpha \hat{\zeta} \xi \hat{v} v \theta \eta \mu$ ' $\dot{\varepsilon} \hat{\eta} \zeta, 46)$. After years of exile, Oedipus has finally arrived.

Read in the light of the Oedipus Tyrannus, the arrival in the sacred grove feels like a return. By crossing the boundary of the precinct, Oedipus re-enacts another unwitting trespass on to a space that is numinous and female, chthonic and forbidden-namely, the womb of his mother. And yet the repetition of the original transgression appears to invert its consequences. Oedipus, once hated by the gods, is now welcomed by them, as Ismene spells out later in the play

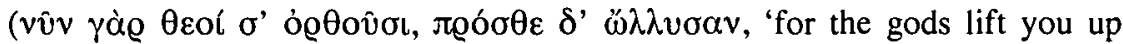
now, but before they destroyed you', 394). Whereas he had once tried to flee the body of his mother, in the aftermath of incest his hopes have turned to the

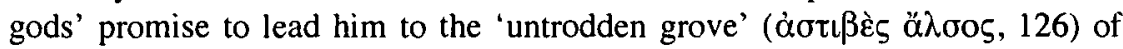
the Eumenides. The realisation of these hopes recalls the traumatic last scene of the Tyrannus. Recall Oedipus' words upon his return from Jocasta's quarters, eyes streaming blood: 'Yet I know this much: no sickness and no other thing will kill me. I would never have been saved from death if not for some strange

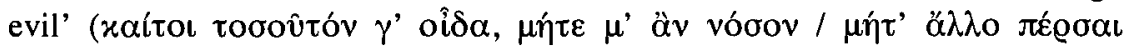

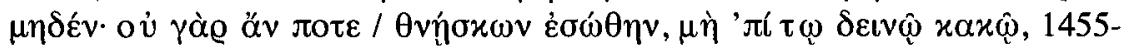
57). ${ }^{13}$ The fate for which Oedipus has been saved is indeed 'strange' - the adjective deinos appears repeatedly in Oedipus at Colonus. But, through the inverted logic of repetition, the foreseen evil becomes a blessing to be granted by merciful gods. The opening scene is positioned as the realisation of the gods' promised closure.

The moment that Antigone seats Oedipus in the grove, then, the play seems almost to be over. That it keeps going for another sixteen hundred lines suggests that the conditions under which Oedipus makes his way to the gods are more complicated. Most important, Theseus has to be brought into the picture. 
Oedipus undertakes this task by enlisting the local to pass along an enigmatic message to the king, namely that 'he will receive a great gain by rendering a

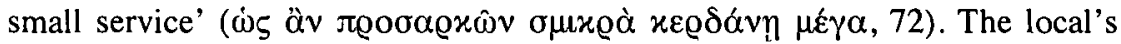
decision first to seek advice from his fellow citizens as to whether the stranger should be allowed to remain highlights just why Theseus is so important. Simply put, Oedipus' seat in the grove is not secure. What Theseus offers, according to the pact he cements with Oedipus, is protection, both in life and in death. In exchange he receives a 'great gain': the apotropaic power that Oedipus' corpse will confer on the city.

It is worth pausing for a moment on the logic of this exchange. For it promises nothing less than a resignification of the trophe that has bound Oedipus and Antigone through countless years of exile. For these years, Oedipus, denied a place in any political community (äjo $\lambda \iota v, 1357$ ), has been nothing but a bag of bones, wretched flesh. Antigone has served not only as prop but as life support, ensuring that her father's basic needs are met. In so doing, she has reciprocated-in stark contrast with her brothers, as Oedipus repeatedly points out the trophe owed by children to parents. Moreover, her protection of her father's abject body for so many years rehearses her duty to care for his corpse, a duty felt all the more acutely, given the misadventures of that body in life.

The relationship undergoes a radical transformation, however, on the threshold of Athens' borders. As Oedipus moves towards heroisation, his body shifts out of the no-man's-land of exile and into a fraught political space, a pawn caught between competing cities. ${ }^{14}$ The need for care changes accordingly. It is Theseus, backed by the Athenian army, who is capable of blocking Creon from wresting Oedipus from Athens and, in a more symbolic sense, of guarding the sanctity of Oedipus' burial and ensuring his viability as a political force. At the same time, Antigone is moved to the margins. Her inability to protect her father under these changed circumstances will be dramatised with uncommon violence when she is seized by Creon's soldiers in full view of the spectators. The distancing of Antigone from Oedipus will culminate with the play's final scene. Yet it is already under way in the opening sequence, which can be read as a microcosm of the drama itself, enacted both at the level of movement and at the level of language.

Consider, first, how Sophocles choreographs the movement of the principal figures in and around the sacred grove of the Eumenides. ${ }^{15}$ Fearful at the noisy approach of the Chorus, a group of local residents, Oedipus asks Antigone to hide him deeper in the grove of the Eumenides. The locals are indeed eager to ferret out the insolent stranger (Antigone does not exist as far as they are concerned until she becomes useful as her father's guide). The hunt is cut short, however, by Oedipus' surprising decision to step out from his place of concealment and 'turn himself in', thereby repeating and reversing yet another scene from his earlier life: the sequence where he is revealed to be the source of the pollution in the Oedipus Tyrannus. His act is the first step towards his nego- 
tiation of a relationship with the Chorus, a precondition of his meeting with Theseus.

For the process to move forward, however, Oedipus has to retreat from the forbidden ground of the grove and to move to its border, where it is lawful, the Chorus says, for all to speak. Oedipus' choice, in other words, is either to remain isolated with Antigone and the Eumenides or to leave his refuge and trust in the good will of the citizens. It is Antigone who urges him to accede to the inhabitants' request, and she plays a necessary role in his carrying it out. The process begins with him laying his hand in hers, and it ends with her leaning her body against his so he can take his seat on the designated boulder: 'this is

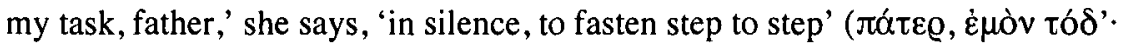

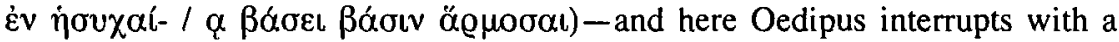

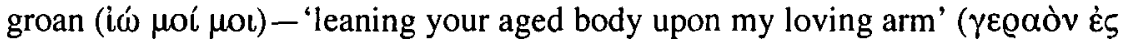

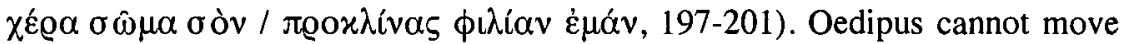
forward without Antigone.

Yet Antigone's role narrows as the Chorus appropriates her function as guide. She 'leads' Oedipus according to the residents' precise cues about the boundaries she has already shown herself to be ignorant of, the instrument of their imperatives. Her very success in carrying out their commands ends up obviating the need for her support since, once seated, Oedipus will remain seated until the moment the gods call him to his death. As I have already emphasised, he will exit the stage without Antigone's help. The sequence thus makes visible Oedipus' temporary retreat from sacred space to the border of political space, cast as the space of dialogue. The choreography dramatises, too, the limits of Oedipus' dependence on Antigone by subordinating her guidance to the directives of the Chorus. What we are watching, then, is a decisive stage in the transfer of Oedipus out of Antigone's hands to the protection of the city.

The subtle renegotiation of Oedipus' attachments also plays out at the level of speech. Antigone is largely silent during the lyric dialogue that her father initiates with the Chorus until the moment when Oedipus, having finally taken his seat, is goaded by the Chorus (and, again, encouraged by Antigone) to reveal his name and lineage. The Chorus, shocked by the revelation, immediately calls on Oedipus to leave the land. It is at this moment that Antigone launches into a plea that adopts the sung, dactylic-based metre of the excited Chorus. ${ }^{16}$ She first positions herself as an extension of and substitute for her father: 'but take pity on me, wretched, I beg you, I who supplicate you for my wretched father, supplicate you meeting your eye with eyes that are not blind' ( $\dot{\alpha} \lambda \lambda$ ' $\dot{\varepsilon} \mu \grave{\varepsilon}$

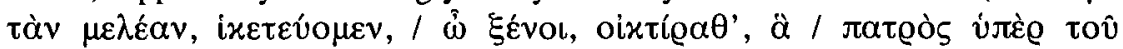

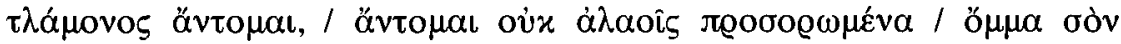
ö $\mu \alpha \sigma ı v, 241-45)$. In a particularly telling turn, she goes on to frame her supplication as an appeal to the Chorus as if they were kin ('[I supplicate you] just

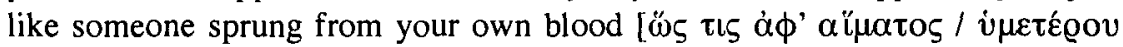

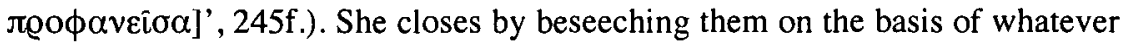
is philon, 'dear', to them: a child, or a wife. But Antigone fails miserably. The 
Chorus, shifting from song into speech as if recoiling from the invitation to blood kinship, refuses to budge.

Oedipus intervenes at this moment with a speech that is almost diametrically opposed to Antigone's. ${ }^{17}$ Mirroring the newly adopted spoken metre of the Chorus, he makes his argument by first invoking the reputation (doxa) of Athens as the refuge and guardian of the downtrodden stranger. ${ }^{18}$ Then, sidestepping as 'unseemly' the actual story of his misfortunes-literally 'the things

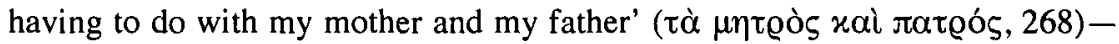
he launches into a clever defence speech through which, by uncoupling action from knowledge, he exonerates himself of responsibility for his crimes in the language of the contemporary lawcourt. Finally, he circles back to appeal to the piety of the Chorus and their civic duty to rescue and guard the suppliant. In short, Oedipus makes his case according to the terms and the measured cadence of Athens' own self-definition, leaving behind Antigone's lyrical entreaty, with its talk of blood-ties and philia. The Chorus responds quite differently this time: awed, they agree to let Theseus decide the matter.

The spoken exchange reenacts the physical dynamics of the scene we have just witnessed while, at the same time, building on its outcome. Antigone had been needed in that case to mediate between Oedipus and the Chorus, not only because they cannot cross the boundary of the sanctuary but because, as we shall see further below, only she (and Ismene) can touch Oedipus' body. From his seat at the border, however, and in the medium of words, Oedipus can communicate with the Chorus directly. The triangulated scenario through which Antigone tries to stand in for Oedipus - and in such a way that suggests the enactment of an old routine from their years in exile together-is, accordingly, supplanted by the dialogue that Oedipus initiates with the Chorus. That dialogue serves, in turn, as a rehearsal for the encounter between Oedipus and Theseus.

We are not surprised, then, that when Theseus does appear a couple of hundred lines later, he bypasses Antigone altogether to deal with Oedipus directly, recognising their shared experience as exiles and accepting him on the basis of their common lot as mortal men: 'for I know', he says, that being a man (àvìe ఓvv, 567), tomorrow my lot may be no better than yours'. The conversation leads to the pact between the two men that guarantees the transfer of Oedipus to Athens. Theseus, acknowledging Oedipus as both a friend and a suppliant, ac-

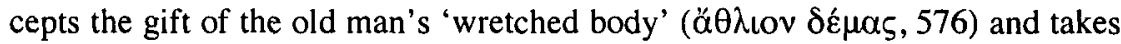
responsibility for burying him. From this point on, Oedipus is securely under Athenian protection.

Both at the level of movement and at the level of language, then, the first scenes of the Oedipus at Colonus steadily unravel the symbiotic bond between Oedipus and Antigone while allowing Oedipus to forge a relationship first with the residents of Colonus, then with Theseus himself. But just as the closure suggested by Oedipus' arrival in the grove of the Eumenides is premature, his affiliation with Athens and its king is destabilised by the pull of Thebes. That 


\section{BROOKE HOLMES}

power is exercised most visibly by Creon and Polyneices, whose attempts to appropriate Oedipus' sacred power for their own ends constitute the main action of the play after Theseus accepts the gift of the corpse. Yet Thebes also exercises its attraction through the love that binds Oedipus to his daughters. The waning dependence of Oedipus on Antigone that we have been tracing turns out to be part of a less linear, more complicated story, one that reflects Oedipus' position for the duration of the tragedy on a line between the space of the city and a sacred-forbidden domain. Even after Oedipus' body is secured as a gift to Athens, it remains an object of contestation between his daughters and Theseus. I turn now to consider the dynamics of this contest as it plays out in dramatic space.

\section{The Family Plot}

I have focused a good deal on the movement of Oedipus' own body in the opening scenes of the tragedy. Sophocles is equally attentive to the movements that Oedipus, saddled with the pollution of his crimes and increasingly invested with sacred power, causes in the bodies around him. One of the first things the Chorus asks of him, before they even know who he is, is to abhor

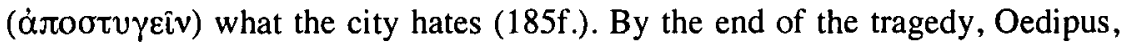
in a preview of his corpse's apotropaic power, has helped drive away two figures who have no place in Athens: the tyrant and the son who, having failed to repay his parents' trophe, is careening towards fratricide. But while the effect he has on Creon and Polyneices is ultimately that of repulsion, he is an object of attraction for his two daughters (who are also, of course, his sisters). Few critics, in fact, have failed to observe the extraordinary love that binds Oedipus as father (and brother) to Antigone and Ismene. Yet such love threatens to undermine the second part of the Chorus' demand, that Oedipus 'reverence what

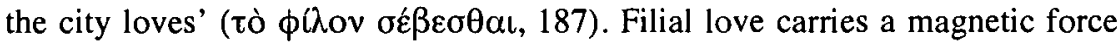
that pulls against the attachments demanded by Athens.

We can get a sense of that magnetism by going back to the moment where the Chorus, persuaded by Oedipus' reasoned appeal to Athenian values, agrees to fetch Theseus. The discussion is suddenly interrupted by Antigone, who excitedly announces the arrival of her sister Ismene, who has been fulfilling her filial duty to her father by serving as his eyes and ears in Thebes. The news she brings now ratchets up the political stakes of Oedipus' transfer to the city: oracles have revealed that Oedipus' corpse has a decisive role to play in his sons' struggle for control of the Theban throne and the future security of the city. Yet at the same time, Ismene directs our attention back to Oedipus' bond with-and dependence on-his daughters. The mention of Polyneices and Eteocles causes Oedipus to dwell at length on how his daughters have assumed the responsibility of his trophe. These bonds of care are at the same time performed on stage. Ismene's arrival provokes a run of affectionate kin-words, including the charged word 'of the same blood' (ö $\mu \alpha \mu \mathrm{ov}, 323,330$ ), used twice of Ismene and then a third time of the brothers (described as $\alpha \dot{v} \theta 0$ ó $\alpha \mu \mathrm{ol}, 335$ ). 
The language of kinship is mirrored in movement. Touching her sister and her father, Ismene creates a filial tableau that contrasts with the respectful distance that the Chorus maintains from Oedipus. That tableau is an important element in the dramatisation of Oedipus' halting transfer to the care of the polis, a visual Leitmotiv that subtly cues the tenacious attraction of Oedipus' daughters. It recurs, as we shall see below, right before Oedipus' death. And it appears, too, after Antigone and Ismene return on stage after having been rescued by Theseus from Creon's soldiers, in a scene worth examining closer for the light it sheds on the precise nature of these bonds of care and kinship.

The scene turns on Oedipus' reunion with his daughters after they have been abducted by Creon. Overcome with gratitude for their saviour, Oedipus asks Theseus for his hand to touch and his cheek to kiss before almost immediately checking himself. Remembering the pollution that isolates him from Theseus, he despairs: 'how can I, being wretched, wish you to touch a man in whom

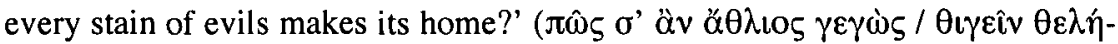

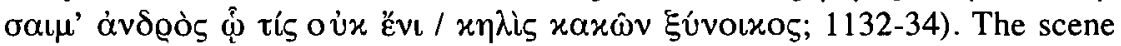
recalls a moment from Euripides' Heracles, perhaps staged a decade earlier, where, in the aftermath of Heracles' murder of his wife and children, another incarnation of Theseus rejects Heracles' concerns about miasma and invites him to smear his blood-stained hands on his cloak (E. Her. 1400). By contrast, the Sophoclean Theseus makes no effort to cross the gulf that divides him from the polluted suppliant. The distance he keeps clarifies the nature of the relationship negotiated between the two men, a relationship expressed through the spoken contract. ${ }^{19}$ After all, it is only because Oedipus' death is miraculous-that is, it will not involve a corpse - that Theseus can 'bury' him. The invisible line separating Oedipus from Theseus brings into relief the proximity that is so crucial to his bond with his daughters and, more specifically, the importance of touch.

Touch, of course, is of particular value to the blind.$^{20}$ But its place in Oedipus' relationship to Antigone and Ismene goes back even before the crisis of the Oedipus Tyrannus. What Oedipus wants more than anything at the end of that play-it is really the only thing he wants - is to touch his daughters again ( $\psi \alpha \hat{v} \sigma \alpha \imath, 1467 ; \theta \iota \gamma \omega \dot{v}, 1469$ ), the daughters who have 'always had a share in

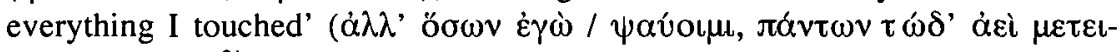
$\chi \varepsilon \dot{\tau} \eta v, 1464 f$.). ${ }^{2 !}$ The line is echoed in the Coloneus. Immediately after Oedipus recoils from touching Theseus, he observes of his daughters: 'they alone of mortals, already experienced in these troubles, can bear them with me' (Tois

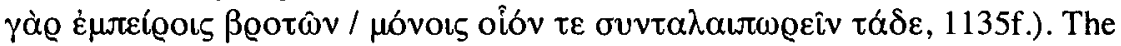
bearing-together of which Oedipus speaks is undertaken literally through physical contact. When Oedipus has Antigone lead him out of the sacred grove

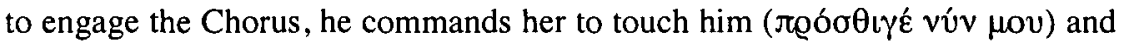

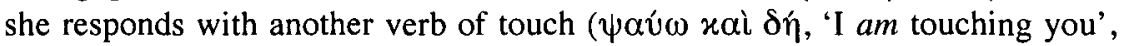
173). He greets Ismene, too, with a demand for touch ( $\pi \varrho o ́ \sigma \psi \alpha v \sigma o v, \omega \mathfrak{3} \pi \alpha \hat{\imath})$;

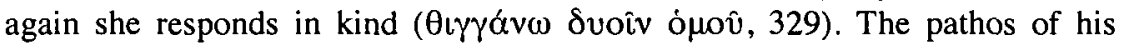




\section{BROOKE HOLMES}

separation from Antigone when she is dragged off by Creon's henchman is captured by an aborted embrace: he cries to her to stretch out her hands

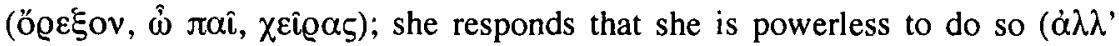

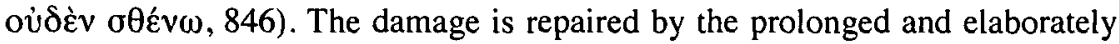
cued embrace that follows the girls' return to the stage (1099-1114).

The embrace obviously concretises the mutual love between Oedipus and his daughters. Yet it also suggests a claustrophobic intimacy, echoed by the paronomasia of Oedipus' command that his daughters press close, 'cleaving' - or,

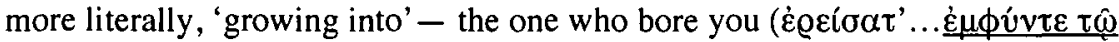
$\phi v 0 \alpha v \tau \iota, 1112 \mathrm{f}$.). ${ }^{22}$ For the entwining of the three figures visually recalls the incestuous tangle of kinship bonds that join them together, casting the care that Antigone provides to Oedipus as an expression not simply of filial duty but of a more troubling fusion of bodies.

Sophocles seems at pains, in fact, to emphasise the incestuous nature of the relationship between Oedipus and his daughters. Just before Theseus arrives on stage, while Ismene is performing the rituals required to absolve her father of the guilt he incurred by trespassing in the grove, the Chorus tries to elicit more details of Oedipus' infamous past. Whereas in his earlier exchange with the local residents he had insisted on spoken metres and legalistic language, this time he shifts into song and starts with what he had earlier avoided entirely: his marriage to his mother.

It is easy to fault the Chorus for their 'prurience' ${ }^{23}$ But to do so misses at least one of the points of the exchange. For the story they drag out of Oedipus resignifies the just-witnessed spectacle of filial affection in the register of the taboo. Although the Chorus has heard rumours of the marriage itself ( $\dot{\omega} s$ $\alpha x o v(\omega, 527)$, they seem ignorant of its issue. Sophocles seems to be playing here with different variants of the Oedipus myth. It appears that in the Oedipodeia, which is no longer extant, Oedipus has his children not with Jocasta but with a second wife, Euryganeia. ${ }^{24}$ The ignorance of the Chorus grants considerable force to the moment when Oedipus gestures to his daughters with the

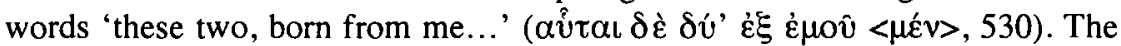
locals' interjections of horrified disbelief drag out the revelation that the girls

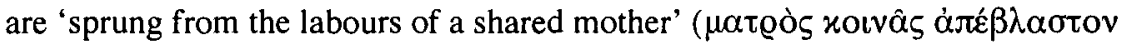

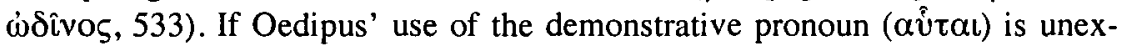
pected, it is, for that reason, all the more effective. Insofar as they are the 'very

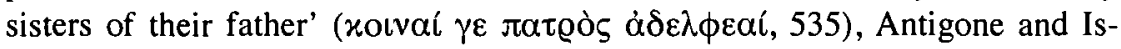
mene are marked as 'two curses' ( $\delta$ v́o $\delta$ ' $\alpha \dot{\tau} \alpha, 532$ ), the living proof of Oedipus' transgressions - in short, the embodiment of incestuous kin-love.

The outbursts of kin-love that punctuate the tragedy, expressed both verbally and visually, make visible the tension between Athens and Thebes over the course of the play, more subtly than Oedipus' encounters with Creon and Polyneices perhaps, but with significant consequences. For those outbursts are also signs of the more specific conflict between different kinds of care to which I alluded earlier. Antigone is the one who has fed and washed and clothed her 
father during countless years of exile, as Oedipus is the first to admit. Again and again he draws a distinction between the care rendered by his daughters and the behaviour of his sons, who allowed their father to be driven from Thebes and failed to concern themselves with his welfare thereafter. Oedipus calls his sons women for sitting at home and neglecting their father, while his daughters make up the deficit of care (trophe) owed by his sons (338-45). But however much Antigone and Ismene are positioned as the ideal sons, the gender inversion is not so straightforward. The care Antigone provides is not so much that expected of a son but that which a mother would provide for a child or a woman for the corpse of a kinsman. Within the specific context of the Labdacid family history, it threatens to consign Oedipus to an eternal embrace representing his entrapment in what I referred to earlier as the 'burial plot of the family', a space and story tangled with incest and fratricide, recurrent curses and dead ends.

Such a plot is precisely what the Coloneus seeks to avoid by reclassifying Oedipus' body as politically significant in death. In this tragedy, Antigone's care, in contrast to the act she performs for Polyneices' corpse in the Antigone, is nothing but a placeholder for the protection afforded by Theseus and Athens (although even in the Antigone, it is the state that ultimately takes responsibility for Polyneices' body). Nevertheless, the claim that Antigone might exercise on her father's corpse hovers quietly in the background of the tragedy, obliquely visible through the language of touch. Much depends, then, on how such a claim will be negotiated when the time comes for Oedipus to die. Despite the fact that the tragedy has been working from the start to shift Oedipus' body out of Antigone's hands into the domain of the city, Labdacid love exercises unusual powers of attraction. In the end, however, Oedipus will prove just as adept at rejecting its claims as he was at repelling Creon and Polyneices, disentangling himself from his daughters and especially the care of Antigone on the threshold of his miraculous death.

The closing sequence of the tragedy begins immediately after Polyneices, the final challenge to Oedipus' burial at Athens, has been driven away from Athens under a rain of curses. Immediately after he exits, the gods' thunder sounds, summoning Oedipus to his death. But the task of separating Oedipus from his daughters remains. That he calls out to them ( $\hat{\omega} \tau \varepsilon \dot{\varepsilon} x v \alpha \tau \varepsilon x v \alpha, 1457$ ) when he hears the thunder suggests, for a split second, that the three figures might again join hands in another enactment of the filial tableau that is, by this point, familiar. But what Oedipus wants instead is for the girls to fetch Theseus so he can make his way to his death: the family triad is yielding to the dyad of two male heroes, united by a sacro-political secret.

Part of the reason Oedipus is able to make this transition is that he no longer requires any physical help in reaching his destination, as I stressed earlier. Rather, he will himself lead, untouched by a guide ( $\chi \hat{\omega} \varrho 0 v \mu \dot{\varepsilon} v \alpha$ v̀tò $\zeta \alpha$ v่tix'

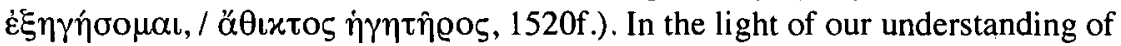
touch as a conduit of incestuous love, we can better appreciate the force of the 


\section{BROOKE HOLMES}

alpha-privative adjective $\ddot{\alpha} \theta \iota x \tau o \varsigma$, 'untouched', which is recharged by Oedi-

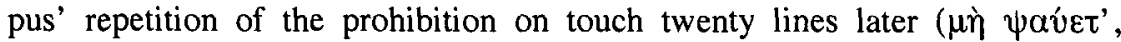
1544). Although Antigone and Ismene will wash and prepare their father while he is still alive for burial (1602f.), ${ }^{25}$ our last image of him anticipates his final separation from his daughters on the bronze threshold beyond which he travels first with Theseus, then alone.

As we have seen before, the logic of the actors' movements is mirrored in words. The dissolution of the filial tableau finds its echo in the speech, reported by the messenger, in which Oedipus declares the end of his daughters' care (trophe $\vec{e}$ of him. One word, he continues, lightens the burden of those toils: love. But his mention of love leads to his announcement of its abrupt termination:

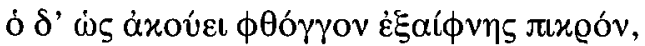

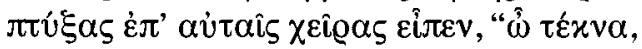

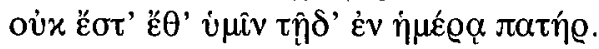

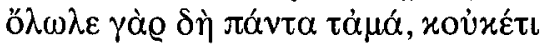

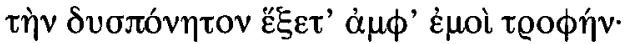

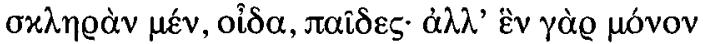

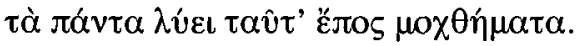

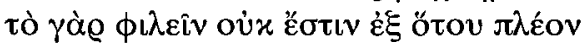

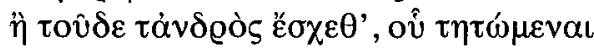

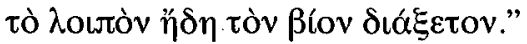

(OC 1610-19)

And when he heard their sudden bitter cry he put his arms around them, and said: 'My children, this day ends your father's life. For now all has perished that was mine, and you will no longer bear the burden of tending me-no light one, I know well, my children; yet one small word releases all these toils: for there will never be more loving from some man more than you had from this one, deprived of whom you must live out the remainder of your life.'

Oedipus' relationship to his daughters has been defined by the love they feel for one another as well as by Oedipus' dependence on Antigone and Ismene for his sustenance. That love, however, could flourish only as long as touch could be maintained: love, Oedipus suggests, disappears with the body that it sustained. Such ephemerality would seem to stand in contrast to the longevity of the hatred nourished by Oedipus' corpse and sustained by the curses against his sons. It conflicts, too, with the sense in the Antigone that love transcends the boundary of life and death: Antigone, recall, frames her burial of Polyneices as an act of devotion that secures her place with her family in the underworld.

Or perhaps we should see the extinction of love as enacted asymmetrically. For Antigone insists that the force of the love she and Ismene feel for their fa- 
ther extends beyond the grave in the Coloneus, too (1700-03). At the same time, Oedipus' parting words, even as they mark a point of closure, suggest that his daughters will be haunted henceforth by their relationship with their father: Oedipus' words, 'for there will never be more loving from some man more than you had from this one', subtly perpetuate the curse of incest beyond his death. ${ }^{26}$ Oedipus, then, unilaterally preempts the claim of transcendent, intrafamilial love. By entrusting Theseus with the task of his burial, a task remarkable precisely because it does not involve touch-indeed, it is not really a burial at all-he appears to escape the incestuous bed once and for all. ${ }^{27}$ Yet the outcome is less clear for his daughters. The climate of uncertainty is magnified by the final scene.

In the parting scene, neither Antigone nor Ismene does much to stop Oedipus from slipping out of their hands. The absence of overt resistance reflects the pattern we have tracked over the course of the play and enables Oedipus to carry out his plan without obstruction. Moreover, any claim the daughters have on their fathers' corpse has remained in the background, overshadowed by the demands of Creon, Polyneices, and ultimately Theseus. The claim of Theseus, in particular, would seem to preempt the need to make a stand over the burial of the corpse, as Antigone so compellingly does in the Antigone. It is as if, in the Oedipus at Colonus, Antigone's care of the abject body is exhausted in life. Oedipus' success in negotiating the conditions for that body in death render her obsolete, as the finality of his last words to Antigone and Ismene makes clear.

And yet, Antigone, in the end, does not disappear so easily in the Coloneus. Her potential for resistance, suppressed over the course of the play, erupts upon her return to the stage after Oedipus' death; the claim on Oedipus after death finally surfaces.$^{28}$ Following the messenger speech, Antigone and Ismene enter, mourning and lamenting the curse on their blood handed down by their father

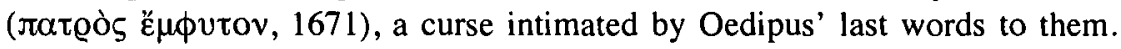
Even though the daughters take centre stage here for the first time since the play began, they continue to define themselves in relationship to Oedipus. In fact, the attractive force binding them to Oedipus shows more nakedly in his absence. Ismene appeals to Hades to 'join me in death to my aged father' (1689f.); Antigone recalls the sweetness of his embrace (1699).

Antigone then slowly begins to focus on the conditions of her father's death, lamenting that he died 'bereft' ( $\dot{\varepsilon} \varrho \hat{\eta} \mu \circ \varsigma, 1714)$ of $h e r,{ }^{29}$ before announcing

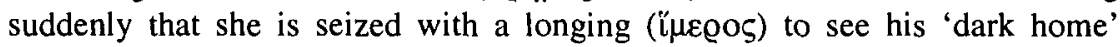
(1725). It is at this moment that the Antigone (and, perhaps, Euripides' Phoenissae and Aeschylus' Septem) begins to haunt the scene more insistently. That play opens with Antigone-there, too, lamenting the evils handed down by Oedipus-enlisting Ismene in her plan to bury their brother in defiance of Creon's edicts. Ismene recoils from transgressing the laws of the city and fighting against those stronger than her. In the Coloneus, she similarly resists Antigone's desire, this time on the grounds that it is not themis, 'lawful', for her to pursue it, the same language that Theseus will use again some lines later when 


\section{BROOKE HOLMES}

he more forcefully denies Antigone's request to look upon the tomb of her father. Antigone responds to Ismene with the suicidal fervour that spectators of the Antigone have found so unnerving: 'lead me there' - that is, to the site

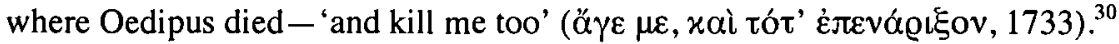

Yet even as the scene recalls the Antigone, it rewrites it by redistributing the weight of sacred power. The language of 'lawfulness' used here (themis, themiton), in contrast with the language of nomos that appears at the beginning of the Antigone (e.g., 59), encompasses both what is dictated by the gods and what is observed by mortals. Whereas in the earlier play, Antigone claims the gods for her side-and would seem to have that claim vindicated, at least in part, by the gods' refusal to accept the city's sacrifices, reported by Teiresias after she leaves the stage-here they are firmly on the side of Oedipus and his surrogate son, as the final summons to Oedipus makes clear. Antigone thus has no ground on which to make a claim besides love, and love is precisely what Oedipus cuts off in the moments leading up to his death, effectively delivering his daughters to a future severed both from his own and from that of Athens. It is no surprise, then, that the showdown between Antigone and Theseus is as ephemeral as the showdown between Antigone and Creon (in the Antigone) is endlessly unresolvable. As soon as Theseus reports Oedipus' final instructions that his tomb not be approached, Antigone acquiesces.

Nevertheless, the force of Antigone's demand does not dissipate entirely. A number of critics have argued that her attachment to her father is displaced on to her brother Polyneices (or, more accurately, her brothers), a transfer that seems to be happening before our very eyes. In the very breath that she yields to Theseus on the matter of her father's tomb she turns her attention to the impending conflict between her brothers, demanding to be sent back to Thebes. The displacement has already been anticipated by the scene just prior to Oedipus' exit, when Polyneices arrives in the hope of securing his father's backing. Once his hopes are dashed, he turns to his sisters, certain of his imminent death, and begs them to bury him with due rites. It is as if we are watching the noose tightening around Antigone's own neck. When she runs off stage in the direction of Thebes at the end of the play, most critics assume she is running headlong into the Antigone..$^{31}$ I want to close by seeing what might happen if we call that assumption into question.

\section{Openended Antigone}

At the beginning of this paper, I stressed the complicated relationship of the Oedipus at Colonus to Sophocles' other two 'Theban' plays, the Oedipus Tyrannus and Antigone. In the case of the former, the Oedipus at Colonus can be seen as rewriting the events of the earlier play. The Antigone is trickier: while the play probably predates the Coloneus by over three decades, the events it describes unfold after the action of the later play. The implied allusions to those events thus seem to project them as the imminent future of the Coloneus. 
But, at the same time, as I have tried to show, much as it plays with its 'prequel', the later tragedy also plays with its 'sequel'. Rather than Antigone defiantly laying claim to a beloved (dead) body rejected by the city, in the Coloneus she slowly lets go of the beloved (live) body under her care so that it can be claimed by the city in death. The overt conflict is between Thebes and Athens, not between Creon and Antigone. The tension between the daughters, especially Antigone, and the city, while helping shape the trajectory of the tragedy, is largely muted. When it does flare up, in the final scene, it is quickly resolved. After all, by that point, Antigone has already lost control of her father's body. By delaying the overt expression of filial love as a claim on the dead body, the play tames the challenge that such love, with its intimations of incest and its echo of the Antigone, poses to the politicisation of Oedipus' corpse and to the city itself as the beneficiary of that corpse.

These permutations of themes and events familiar from the Antigone do not preclude the Antigone from unfolding just as we imagine it must in the unscripted future of the Coloneus. They can even be seen-and have been seen by some critics - as motivating it: thwarted in her desire to bury her father, Antigone shifts her attachment to Polyneices and the impending drama of his death and burial. Yet I want to insist that tragic repetition understood in these terms is not necessary, or at least not with the straitjacketing that has been assumed. It is enough to recall that Oedipus' burial at Antigone's hands, denied in the Oedipus at Colonus, had been assumed by the Antigone. The polymorphic fecundity of myth is very much at work in the Coloneus even as it summons up Sophocles' earlier Theban plays.

Moreover, contrary to what is often implied, Antigone does not commit herself in the Coloneus to the future presumed by many of her modern readers. Rather, she answers Polyneices' request for burial with a plea for him to turn back from his violent intent and let go of his anger. Even after she recognises that his purpose is fixed, she tries yet again, in vain, to persuade him not to go to his death. When she runs off stage, it is in the hope of averting the fratricide. That hope may be futile. Indeed, most modern scholars have taken her closing lines as the paradigmatic illustration of tragic futility. ${ }^{32}$ Yet I would insist instead on Antigone's own insistence on the possibility of another future, outside the parameters of the Oedipal curse, on her 'blind' hope.$^{33}$ For Antigone articulates her commitments in relationship to life and the hope of life, rather than in relationship to the care of the dead and forms of care that entail death, as in the Antigone. If we fail to see Antigone's orientation towards life, it may in part be because we are ourselves so committed to an Antigone implacable in her resolution to bury her brother and, indeed, to the very idea of tragic necessity. Moreover, the Athenocentric nature of the play primes us to see in Athens the promise of a redemptive future against the foil of a Thebes consigned forever to the repetition of the curse. I want to see what happens if we call these tendencies into question, beginning with the valorisation of Theseus and Athens. 


\section{BROOKE HOLMES}

Antigone's challenge to Theseus appears far more contained than her challenge to Creon: it is short-lived and it does not seem to infect other characters, as in the Antigone. Yet, as we have seen, Antigone acts as a subtle oppositional force over the course of the entire play, occupying a rival centre of gravity that serves as a counterweight to the city and its concerns. Until now, I have allowed her position to be negatively valorised against the positive model of Athens supported by the tragedy and its representation of divine will. But if we resist the privileging of Athens, Antigone can be seen to enact a different kind of contestation, by giving novel expression to an ethic of love indifferent to categories like ally and enemy. The memorable line of another Antigone comes to mind in this context: 'I was born not to hate-together, but to love-together'

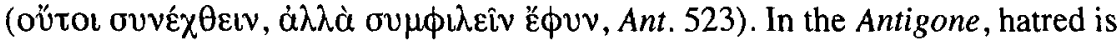
not only what divides Polyneices and Eteocles but also what motivates Creon to differentiate the traitor from the hero, the abject body from the corpse escorted to the underworld with all due rites. The strange task of loving together belongs to an Antigone committed to erasing boundaries and hierarchies and differences within the family (with all the vertigo that sets off).

In the Oedipus at Colonus, however, familial hatred ceases to be a threat to the boundaries of the city, as it is at Thebes, and becomes instead an apotropaic talisman capable of keeping Thebes at bay. For what Oedipus bequeathes to Athens is a legacy of hatred, mobilised in order to defend the boundaries of the city. Antigone and Ismene are initially caught up in this legacy. The Chorus urges Antigone and Ismene to stay on as wards of Theseus, and indeed this seems to be what Oedipus had intended. In the end, however, Athens is no home for them. That may be in part because the daughters are never not two 'curses' ( $\delta$ óo $\delta$ ' ä $\tau \alpha$ ), ruin incarnate and ticking timebomb. ${ }^{34}$ But it is also because Antigone herself rejects her father's wish that she remain the object of Athenian benevolence. If filial love had seemed to be neutralised at the moment Oedipus was transferred into the care of Theseus, a moment that cements the binary of friend and enemy and inscribes the future with the promise of war, Antigone's return to the stage represents its resurgence. Turned away from Oedipus, Antigone redirects the love that had sustained her father, making it again viable through her hope that the curse of intrafamilial conflict can be broken. If we call her naïve or if we insist that we know what has to happen, we fail to recognise how she functions in the final scene as an antidote not just to her father's curse and the Athens whose borders it seals but also to the conflict looming on the horizon. The very viability of Antigone's love means that we do not have to read the closing scene of the tragedy as the final moment before the film loop begins again.

Here the openness with which Antigone approaches life after Oedipus can be imagined as the Coloneus's relationship toward futurity more generally. I suggested at the outset of this article that the structuring of the final scene around the threshold of Antigone's uncertain future posits a space that can be read not only in terms of the pluripotency of myth but also in terms of her reception. For 
the past few decades, the Antigone has been the most popular of the Greek tragedies for philosophers and political theorists interested in working the productive intersections between the past and the present (to say nothing of its popularity in performance around the world).$^{35}$ These strategies of reading often deliberately dislocate the tragedy from its original context or ply its transhistorical resonances. In so doing, they can be seen as responding to the openendedness of the closing scene, where the tragedy, long focused on a particular end, gains an unexpected momentum beyond the boundaries of its Athenian setting. Although the shift into an openended mode is not unique to the Oedipus at Colonus, ${ }^{36}$ it has not been sufficiently recognised as such. Nor has Antigone herself been read as the vehicle of the tragedy's closing potentialities.

By reading Antigone in these terms, however, I am not suggesting that she becomes the tabula rasa for our own hopes and desires and ideals, the always available figurehead for contemporary agendas. Antigone at Colonus occupies a complicated position between constraint and freedom. By constraint, I mean that, as I have argued here, she fulfils a particular function in Oedipus' (and Sophocles') endgame, coding the space of the oikos as it enters an agonal relationship with Athens and serving as the remainder of Oedipus' alchemical transformation from pariah to hero. Such a reading is informed by the long history of interpreting the Oedipus at Colonus, the Antigone, and Greek tragedy in general. I have also attended closely to the language and stage cues of the play in the hope of using these clues as constraints, a reminder that the tragedy is not an object of our own making.

It is from a space that is densely scripted that we eventually arrive at the final scene. The more Antigone begins to orient herself towards a world beyond the Coloneus, first in the meeting with Polyneices, then in the final scene, the less she seems reducible to the product and symbol of incestuous, polluted, dead-end love: her stance becomes the embrace of an alternate future, dictated neither by the Labdacid legacy nor by past tragedies. That unexpected shift resembles the creative transformation of Oedipus himself in the Coloneus. Yet at the same time, the emergent Antigone counters the legacy produced by her father's transformation, intimating a politics of the disrupted curse, reconciliation and affirmation. If the hatred of the curse enjoins fatality on its descendants, its counterweight, filial love, insists on the possibility of the future being otherwise. And within that space of possibility, we may find another way of imagining tragedy itself: not as fixed repetition nor as timeless truth but as a machine for generating unexpected futures out of the bones of the past. ${ }^{37}$

\section{Princeton University}

\section{NOTES}

1. For the importance of a concept of home to Oedipus' story, see Zeitlin (1990b), 132; see also 155-58 on Oedipus at Colonus.

2. Zeitlin (1990b), 131 . 


\section{BROOKE HOLMES}

3. The contrast between closure and openness is strong enough for some critics to complain that Sophocles should have ended the play with the messenger speech. See, e.g., the comments of Waldock (1956), 271: '...Sophocles unduly spins out the ending. Antigone and Ismene have really nothing to say and they say it to the tune of too many verses.'

4. Lacan (1992), 243-87; Irigaray (1974), 214-26; Irigaray (2010); Butler (2000). For an overview of these readings, see Burian (2010). On the contemporary reception of Antigone, see also Holmes (2012), 150-80, with further bibliography.

5. See, e.g., Winnington-Ingram (1954), 24; Taplin (1983), 162f.; Zeitlin (1990b), 161-63; Alaux (1992), 228f ; Markantonatos (2002), 147-60; Markantonatos (2007), 118; Dunn (2012), $273 f$.

6. Saxonhouse (2005) offers an 'Antigone becoming Antigone' reading of Euripides' Phoenissae, although the Euripidean Antigone represents a different endpoint than the hero of Sophocles' Antigone. For a sketchy 'prequel' reading, see also O'Connell (1967). On the unity of Antigone across the three Theban plays, see Johnson (1997); Griffith (2005b), 94f.

7. For the tradition of Oedipus' death at Thebes, see also Il. 23.677-80; Aesch. Sept. 914-1004. But we should also be wary of presuming a univocal archaic tradition of myths surrounding Oedipus and his family: see Mastronarde (2004), 17f.

8. Seidensticker (1972); Markantonatos (2007), 203-16.

9. See E. Ph. 1650-1746. Antigone first declares she will bury her brother at whatever cost but then seems to decide instead to accompany her father in exile to Colonus, where he is fated to die 'after wandering' (1744-46 remain difficult to accommodate here and may be interpolated): see Mastronarde (2004), 592f., 638f. A similar problem lingers in straightforward interpretations of the Antigone as the sequel to the Oedipus at Colonus, insofar as it is hard to reconcile Antigone's many years of wandering and lost maidenhood with her characterisation in the Antigone as 'girl' ( $x$ ón, e.g., 395, 769) and 'child' ( $\pi \alpha i s, ~ e . g ., ~ 378,561,654$ ) or Oedipus' own marking of time passed in exile at $O C$ 395. We know little about Euripides' lost Antigone except that it involved the marriage of Antigone and Haemon. But it is clearly marked by Euripidean inventiveness.

10. '...although the tangle of unmanageable forces with which Antigone is implicated at Colonus prompts the audience to recall relevant Theban disasters, the frustratingly replicated sequences end on a positive note. It is therefore hard to escape the conclusion that an indispensable part of the intertextual strategy of Oedipus at Colonus is the decisive inversion of those previous tragedies intimately connected with the legend of Thebes': Markantonatos (2007), 216. See also Markantonatos (2002), 161-65. Yet Markantonatos does not doubt that the events at Thebes will unfold in their tragically fated terms. He argues that the fact that the audience has this knowledge gives them a less positive perspective on Theseus, who fails to protect Antigone and Ismene: Markantonatos (2007), 221.

11. Markantonatos (2007), 223. On an 'Athenian' or democratic Antigone (in the Antigone), see Foley (1995); Patterson (2006), 35-39. Cf. Honig (2009), who argues that Antigone takes a stand that is political but not democratic.

12. See, e.g., Ant. 988-90, 1087; OT 444, 1292; Pho. 834. On similarities between Oedipus and Teiresias, see Ahrensdorf (2009), $51-55$.

13. I am not arguing that the end of the Oedipus Tyrannus deliberately anticipates the plot of the Oedipus at Colonus. Such a suspicion has led to a prolonged debate about whether the ending of the $O T$ is genuine or, rather, interpolated by someone aware of the $O C$. Rather, I see the $O T$ closing with an openendedness that is not in itself suspect nor unlike the openendedness of the $O C$ (discussed further below). The case for interpolation is made most forcefully by Dawe (2001). For arguments in favour of the authenticity of the final scene, see Davies (1982 and 1991a), where he defends the idea that the $O T$ ends 'with a carefully contrived uncertainty and suspension' that is 'extremely Sophoclean' (1991a, 9); Budelmann (2006), 57-59; Finglass (2009); on the non-closure of the final scene in the $O T$, see further Burian (2009). These debates do not prevent us from recognising that the events of the $O C$ can be retrospectively seen as a realisation of Oedipus' ambiguous remarks about his future in the $O T$ (and probably were seen this way).

14. The bibliography on Oedipus' political status is considerable. See esp. Easterling (1997), 276; Vidal-Naquet (1996).

15. The importance of the grove and its boundaries to expressing the tragedy's major themes has been stressed by a number of critics (without the specific relationship between Oedipus and Antigone being analysed): see esp. Dunn (1992); Edmunds (1996); Markantonatos (2007), 72-80.

16. Taplin (1985), $118 \mathrm{n} .6$, observes that Antigone's lines here are 'the nearest Sophocles comes to Euripidean monody'. 


\section{ANTIGONE AT COLONUS AND THE END(S) OF TRAGEDY}

17. Ancient scholiasts recognised the clear contrast of genres here: see $\Sigma$ on 237 de Marco

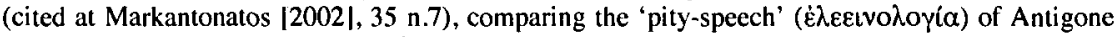

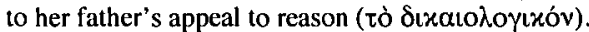

18. On the Athenian values invoked here and the interest of the play in 'the evolution of the Athenian community's moral perspective', see Slatkin (1986).

19. On the restriction of touch between adult males in tragedy, see Kosak (1999), esp. 93-99.

20. See, for example, E. Ph. 1693f., 1699f. (Oedipus seeks to touch the corpses of his family members).

21. He is making specific reference to sharing meals with his young daughters. Johnson (1997), $377 \mathrm{f}$., draws attention to how unusual this would have been, both in contemporary Athens and in an imagined heroic age. For a defence of the authenticity of these lines, see Davies (1991a), 10-12, and Finglass (2007), 46-54, esp. 46f., against Dawe (2001), 6-11; on the end of the play more generally, see $n .13$ above.

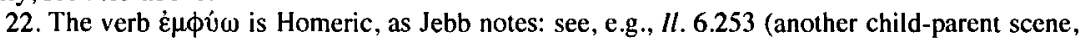
with Hecuba greeting Hector on his return to the citadel), Od. 10.397.

23. Knox (1964), 152.

24. See Oedipodeia Fr. 1 in West (2003). Pausanias argues that the indication at $O d .11 .274$ that the gods revealed the incest 'straightaway' (ä $\phi \alpha \varrho)$ means that there was no time for Jocasta to bear Oedipus four children and concludes that Euryganeia was the mother of his offspring (9.5.10f.). See also Pherecydes FGrH 3 F 95 and Peisandros FGrH 16 F 10, with Lloyd-Jones (2002), 9f.; Mastronarde (2004), 20-22, 31-38 (on the Peisander Scholion). On the basis of the extant evidence, March (1987), 138, 141-45, concludes that in pre-tragic versions of the Oedipus myth, Eury'ganeia was the mother to Oedipus' children (she credits Aeschylus with giving Jocasta this role and therefore heightening the horror of Oedipus' story). See also Jebb (1900), 92 ad 534.

25 . See also 1639, the last time Oedipus touches ( $\psi \alpha u ́ \sigma \alpha \varsigma)$ his daughters before departing.

26. I am grateful to Bonnie Honig for pushing me to see this point.

27. For the association of burial and a 'common bed', see S. Ant. $71-74$ (xeivov $\delta$ ' غ̇yò) /

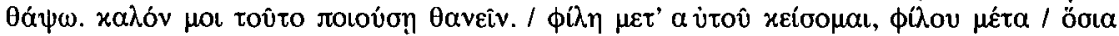

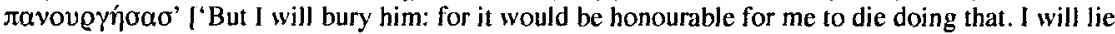
loved with him, loved, having dared a righteous crime' (); see also 524f. Antigone stresses in the Antigone that she and Polyneices came from the same womb (e.g., 466 and esp. 511: toùs

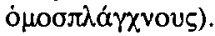

28. On the tumultuous feel of the exodos, see Markantonatos (2002), 147-60.

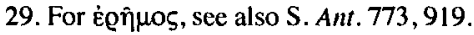

30. On the unnerving quality of Antigone (in the eponymous play), see Griffith (2005b). For a different take on Antigone's behaviour as a shock to the audience, see Sourvinou-Inwood (1990). On the disruptive force of female lament more generally in the Antigone, see Segal (1995), 119-37.

31. See n.5 above.

32. Cf. Dawe (1967), who sees in Antigone's hopefulness an attempt by Sophocles 'to diminish any feeling in the audience's mind that there is still something to come' (18). (Dawe, it should be noted, is more interested in defending his views on the end of the Septem than in a reading of the $O C$.) The critical investment in Antigone as a paradigm of tragic futility can be seen in Davies' characterisation of Dawe's reading as 'as wrong as is humanly possible': Davies (199/b), $271 \mathrm{n} .10$.

33. Butler (2000), 65, also sees the Oedipus at Colonus as destabilising the father's curse but reads this curse in terms of kinship norms.

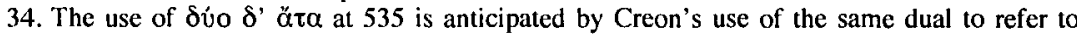
Antigone and Ismene at S. Ant. 533 as 'vipers' who lie in the house, secretly drinking the king's blood.

35. On its place in contemporary theory, see n.4 above. On the contemporary international performance tradition, see Goff and Simpson (2007); Wilmer and Žukauskaite (2010), esp. the essays in section IV; Mee and Foley (2011).

36. On uncertain endings as a peculiarly Sophoclean technique, see Roberts (1988), 188-94; Davies (1991a), $9 f$. See also Budelmann (2006), esp. 45f., on the concept of the 'mediated ending', and $n .13$ above on the handling of closure in the $O T$.

37. I am grateful to audiences at Duke, University of North Carolina-Chapel Hill, New York University and Princeton for their feedback on an earlier version of this paper. I am indebted, too, to the anonymous reviewers for Ramus and especially Nancy Worman, Froma Zeitlin and Bonnie Honig for their comments, criticisms and encouragement. 